\title{
Study of Epstein Barr virus, Human Herpes 6 and Human Herpes 7 in Children with Acute Lymphoblastic Leukemia
}

\author{
Mohamed Anies Rizk ${ }^{*}$ and Ahmad Darwish ${ }^{2}$ \\ ${ }^{1}$ Clinical Pathology Department, Mansoura Faculty of Medicine, Egypt \\ ${ }^{2}$ Pediatric Department, Mansoura Faculty of Medicine, Egypt \\ *Corresponding author
}

\begin{tabular}{l} 
Ke y w or d s \\
ALL, EBV, HHV6, \\
HHV7, Real time \\
PCR \\
Article Info \\
$\begin{array}{l}\text { Accepted: } \\
\text { 04 February } 2019 \\
\text { Available Online: } \\
\text { 10 March } 2019\end{array}$ \\
\hline
\end{tabular}

The aim of the present study is to identify the presence of Epestein Barr virus (EBV), Human Herpes virus 6 (HHV6)and Human Herpes virus 7 (HHV7) by molecular methods in newly diagnosed ALL in children and to correlate their presence with clinical and immunophenotypes of ALL. The present study included 60 children at the time of diagnosis of ALL before start of the therapy and 60 healthy cross match age and sex children as a control group. The study of EBV, HHC6 and HHV7 was carried out by real time polymerase chain reaction (PCR). In comparison between the prevalence of EBV, HHV6, HHV7 between patients and control there was statistically significant increase in prevalence rates (31.7 versus 1.7 for EBV, $16.7 \%$ versus $3.3 \%$ for HHV6 and $13.3 \%$ versus $8.3 \%$ for $\mathrm{HHV7}$ respectively, $\mathrm{P}=0.0001)$. Moreover, the mean $\pm \mathrm{SD}$ copies $/ \mathrm{ml}$ was statistically significant higher for HHV6 in patients compared to the controls $(\mathrm{P}=0.0001)$. There was significant association between EBV and HHV6 infection in patients $(\mathrm{P}=0.001)$. In $\mathrm{EBV}+\mathrm{ALL}$, there was significant higher rates of hepatosplenomegaly $(47.4 \%, \mathrm{P}=0.01)$ In conclusion, EBV, HHV6 and HHV7 viruses were present in high rates in ALL which suggest a role for these viruses in pathogenesis of ALL. Further studies are required to validate this hypothesis.

\section{Introduction}

Acute lymphoblastic leukemia (ALL) is a global health burden especially in children. It represents a common malignancy of childhood. There are many new therapies that have been developed and there is a marked improvement of its outcome with around $68.2 \%$ five years survival. However, its pathogenesis remains a puzzle that needs to be resolved to be able to reduce its incidence. Among factors that may be associated with development of ALL are infectious agents. The infectious etiology of development of ALL is based upon two theories. The first one is associated with direct oncogenic mechanism due to expression of viral oncogenes and down regulation of tumor suppressor genes leading to cellular transformation ${ }^{[1,2]}$. The other mechanism of oncogenesis due to infection claims the inflammatory reactions associated with infections that leads to immunosuppression with loss of immune surveillance mechanisms 
or/and production of dome mutated products that lead to development of ALL ${ }^{[3]}$. The first mechanism of infectious agents associated with ALL is thought to act within the cells and leads to clonal expansion with the infectious particles carried in all expanded tumor cells ${ }^{[4]}$. The example for the first theory of infections associated with ALL are latent viral infections associated with herpes viruses such as human Herpes virus 6 (HHV6), human Herpes virus 7 (HHV7) and Epstein barr (EBV) virus.

Epstein barr virus is very common around the world infecting about $89 \%$ of the children and around $90 \%$ of the adults ${ }^{[5]}$.The common cellular target of EBV virus is B lymphocytes with persistence of the virus in memory cells [6], however, there is growing evidences support that it may also infects $\mathrm{T}$ lymphocytes and natural killer cells with long persistent latent infection. The association of EBV with malignancy is well known with varieties of malignancies such as Burkitt's lymphoma, Hodgkin's lymphoma and nasopharyngeal carcinoma ${ }^{[7]}$.

The other viruses that are claimed to be associated with oncogenesis are human HHV6, and HHV7. These viruses infect young children with mild clinical signs such as fever and exanthema subitum HHV6 with complete cure and development of persistent and infection ${ }^{[8]}$. The persistence of herpes viruses occurs usually in salivary gland and mononuclear cells in the blood. The reactivation usually occurs in immune compromised conditions leading to severe infections such as encephalitis and retinitis ${ }^{[9]}$. The presence of high viral load with children with ALL was previously described ${ }^{[10]}$.

The aim of the present study is to identify the presence of EB, HHV6 and HHV7 by molecular methods in newly diagnosed ALL in children and to correlate their presence with clinical and immune phenotypes of ALL.

\section{Materials and Methods}

The present study included 60 children at the time of diagnosis of ALL before start of the therapy from Mansoura Oncology centre, Egypt from March 2015 till January 2018.In addition to 60 healthy children were included as control group with no hematological disorders and with similar sex and age distribution. Children with other hematological malignancies or who started the therapy were excluded. The diagnosis of ALL was performed according to WHO 2008 criteria was established on the basis of the latest diagnostic criteria of WHO2008, including morphology and immune phenotypic markers for B-ALL and TALL ${ }^{[11]}$. The used markers for diagnosis of B-ALL were cCD3, CD2, CD5, CD7, CD8 and the used markers for T-ALL were cCD79, CD10, CD19, CD20, CD22.

The study was approved by Mansoura Faculty of Medicine ethical committee. Approval consents were obtained from the parents of all children.

Each child was subjected to full clinical examination and routine laboratory investigations. Seven milliliter of blood was obtained from each child over EDTA and plasma was separated and DNA was extracted and kept frozen at $-20^{\circ} \mathrm{C}$ until time of amplification.

\section{DNA extraction}

DNA was extracted from plasma samples by the use of QI Aamp DNA blood kits (Qiagen, Hilden, Germany) according to the manufacturer's instructions. Quantification of viral DNA by multiplex real-time PCR for HHV6 and HHV7

Multiplex real time PCR was used to amplify and quantitate HHV6 and HHV7 according to the protocol developed previously ${ }^{[12]}$. 
The amplification mixtures used was supplied by Qiagen. Real-time PCR system and the following protocol: an initial denaturation and polymerase activation step for $15 \mathrm{~min}$ at $95^{\circ} \mathrm{C}$, followed by 50 cycles of denaturation at $94 \circ \mathrm{C}$ for60 $\mathrm{sec}$ and $62^{\circ} \mathrm{C}$ for $90 \mathrm{sec}$. Real-time fluorescent measurements were recorded and a $\mathrm{Ct}$ value for each sample was calculated by determining the point at which the fluorescence exceeded the threshold. Each real-time PCR assay contained a standard dilution series for DNA quantification, and all samples were analyzed in duplicate. Negative controls were added to each run. The standards were plasmid controls that contained the PCR products amplified by each primer set as described previously. For multiplex real-time PCR, each plasmid control was mixed and diluted to produce standard curves. The number of viral DNA copies was calculated from these standard curves and expressed as copies/ml.

\section{EBV by Real-time PCR}

The amplification and quantitation of EBV was performed by real time PCR as previously described ${ }^{[13]}$.

The used primers and probes were summarized in table 1 .

\section{Statistical analysis}

Statistical package for social science program version 24 used for analysis. The quantitative data were presented as mean, standard deviations and ranges. The comparison between the studied groups was done by using One Way Analysis of Variance (ANOVA). P was considered significant $<0.05$

\section{Results and Discussion}

The study included 60 children with ALL their mean age \pm SD were $4.7 \pm 3.4$ years mainly of male gender $(73.3 \%)$. The main clinical signs were mucositis (35\%), fever (31.7\%), lymphadenopathy (31.7\%) and hepatosplenomegaly $(25 \%)$. The majority of the type of ALL was B-ALL (53.3\%) (Table 2).

In comparison between the prevalence of EBV, HHV6, HHV7 between patients and control there was statistically significant increase in prevalence rates (31.7 versus 1.7 for EBV, $16.7 \%$ versus $3.3 \%$ for HHV6 and $13.3 \%$ versus $8.3 \%$ for HHV7 respectively, $\mathrm{P}=0.0001)$. Moreover, the mean $\pm \mathrm{SD}$ copies/ml was statistically significant higher for HHV6 in patients compared to the controls $(\mathrm{P}=0.0001)$ (Table 3$)$.

There was significant association between EBV and HHV6 infection in patients $(\mathrm{P}=0.001)$ (Figure 1). There was increase in the prevalence of EBV (36.8\%), HHV6 (40\%) and HHV7 (75\%) in age above 4 years, however the increase were insignificant $(\mathrm{P}=0.3, \mathrm{P}=0.9, \mathrm{P}=0.1$ respectively) (Table 4$)$.

In the comparison between children with ALL positive for EBV to those negative for EBV, there was significant predominance of male gender $(98.5 \%, \mathrm{P}=0.05)$

In EBV+ ALL, there was significant higher rates of hepatosplenomegaly $(47.4 \%, \mathrm{P}=0.01)$, with significant increase of total leucocytes counts (mean \pm SD 46.5 $\pm 38.5, \mathrm{P}=0.04$ ) and absolute lymphocytosis (mean \pm SD $38.8 \pm 3,2$, $\mathrm{P}=0.02)$. There was significant association between B-ALL and EBV (89.5\%, $\mathrm{P}=0.0001)$ (Table 5).

In comparison between children with ALL positive for HHV6 and negative for HHV6 the only significant clinical sign was hepatosplenomegaly $(80 \%, \mathrm{P}=0.0001)$ (Table $6)$.

In comparison between children with ALL positive for HHV7 and negative for HHV7, the positive children were significantly older 
in age (mean $\pm \mathrm{SD}, 7.7 \pm 2.6, \mathrm{P}=0.0001)$ with significant reduction in hemoglobin level (mean $\pm \mathrm{SD}, 7.7 \pm 2.6, \mathrm{P}=0.0001$ ) (Table 7).

EBV, HHV6 and HHV7 are known latent viruses with persistence lifelong after primary infections. Though, primary infections may passed unnoticed the persistent infections are linked to development of many types of malignancy. In the last few years there are significant links between the presence of EBV and development of leukemia ${ }^{[14]}$.

In the present study EBV-DNA was present in $31.7 \%$ of the children with ALL versus 1.7 for EBV-DNA in control children. Similar results were reported for presence of active EBV associated with leukemia in Egypt either by use of serological markers ${ }^{[15,16]}$ and were online with other studies from different geographical regions $\left[{ }^{17,}{ }^{18]}\right.$. The low prevalence of EBV viremia in the control subjects compared to study by Loutfy et al., $2006^{[15]}$ may be attributed to the difference of the laboratory methods used in both studies. The presence of serological markers of EBV in control subjects are not always indicators of acute EBV infection and even the presence of positive serological markers of EBV are not always present in active infection in immune compromised patients such as ALL.

EBV belongs to herpes virus family and its activation is known to be a nosogenesis of malignant diseases ${ }^{[2]}$. It is well known that EBV leads to chromosome mutations and translocation in lymphocytes that lead to cmyc oncogene activation and excessive expression $^{[19]}$. However, the exact mechanisms associated with development of lymphoproliferative disorders associated with EBV need further extensive studies

Table.1 Viruses and the sequences of the used primers and probes

\begin{tabular}{|l|l|}
\hline Virus & Primers and probes sequences \\
\hline EPV & $\begin{array}{l}\text { F: 5'-CCCAACACTCCACCACACC-3' } \\
\text { R: 5'-TCTTAGGAGCTGTCCGAGGG-3' } \\
\text { 5'-CACACACTACACACACCCACCCGTCTC-3'. }\end{array}$ \\
\hline HHV6 & 5'-TTTGCAGTCATCACGATCGG-3' \\
& 5'-AGAGCGACAAATTGGAGGTTTC-3' \\
& Probe5'-AGCCACAGCAGCCATCTACATCTGTCAA-3' \\
\hline HHV7 & F:5'-CGGAAGTCACTGGAGTAATGACAA-3' \\
& R: 5'-ATGCTTTAAACATCCTTTCTTTCGG-3' \\
& Probe 5'-CTCGCAGATTGCTTGTTGGCCATG-3' \\
\hline
\end{tabular}


Table.2 Demographic, clinical and laboratory data of children with ALL

\begin{tabular}{|c|c|}
\hline $\begin{array}{l}\text { Sex } \\
\text { Male } \\
\text { Female }\end{array}$ & $\begin{array}{ll}44 & 73.3 \% \\
16 & 26.7 \%\end{array}$ \\
\hline Age & $\begin{array}{l}4.7 \pm 3.4 \\
0.5 \\
13.5\end{array}$ \\
\hline Fever & $19 \quad 31.7 \%$ \\
\hline Hepatosplenomegaly & $15 \quad 25 \%$ \\
\hline Lymphadenopathy & $19 \quad 31.7 \%$ \\
\hline mucositis & $21 \quad 35 \%$ \\
\hline $\begin{array}{l}\text { Total leucocytic counts } x \\
10^{3} / \mathrm{mm}^{3} \\
\text { Median } \\
\text { Minimum } \\
\text { Maximum }\end{array}$ & $\begin{array}{l}10.000 \\
1.30 \\
154.00\end{array}$ \\
\hline HB g/dl & $\begin{array}{l}8.1 \pm 2.6 \\
3.1 \\
11.00\end{array}$ \\
\hline $\operatorname{RBCsx10} \%$ & $3.7 \pm 0.9$ \\
\hline Platelets x $10^{3} / \mathrm{mm}^{3}$ & $\begin{array}{l}52.3 \pm 39.3 \\
9.2 \\
188.000\end{array}$ \\
\hline Neutrophil $\times 10^{3} / \mathrm{mm}^{3}$ & $\begin{array}{l}3.03 \pm 2.00 \\
0.8 \\
10.000\end{array}$ \\
\hline $\begin{array}{l}\text { Lymphocytes } \times 10^{3} / \mathrm{mm}^{3} \\
\text { Median } \\
\text { Minimum } \\
\text { Maximum }\end{array}$ & $\begin{array}{l}9.7 \\
0.6 \\
130.00\end{array}$ \\
\hline $\begin{array}{l}\text { Type of ALL } \\
\text { B-ALL } \\
\text { T-ALL }\end{array}$ & $\begin{array}{ll}32 & 53.3 \% \\
28 & 46.7 \%\end{array}$ \\
\hline
\end{tabular}


Table.3 Comparison of EBV, HHV6, HHV7 between patients and control

\begin{tabular}{|c|c|c|c|}
\hline & Patients & Control & $\mathbf{P}$ \\
\hline $\begin{array}{l}\text { EBV-DNA } \\
\text { Mean } \pm \\
\text { (copies/ml) }\end{array}$ & $\begin{array}{l}1931.7 \% \\
9333 \pm 1581.1\end{array}$ & $\begin{array}{l}1 \quad 1.7 \% \\
7000\end{array}$ & $\mathrm{P}=0.0001$ \\
\hline $\begin{array}{l}\text { HHV6 } \\
\text { Mean } \pm \text { SD } \\
\text { (copies/ml) }\end{array}$ & $\begin{array}{l}10 \quad 16.7 \% \\
514 \pm 25\end{array}$ & $\begin{array}{l}2 \quad 3.3 \% \\
505 \pm 21.0\end{array}$ & $\mathrm{P}=0.0001$ \\
\hline $\begin{array}{l}\text { HHV7 } \\
\text { Mean } \pm \text { SD } \\
\text { (copies/ml) }\end{array}$ & $\begin{array}{l}813.3 \% \\
505 \pm 12.9\end{array}$ & $\begin{array}{l}58.3 \% \\
420 \pm 81.5\end{array}$ & $\begin{array}{l}\mathrm{P}=0.0001 \\
\mathrm{P}=0.1\end{array}$ \\
\hline
\end{tabular}

Table.4 Prevalence of EBV, HHV6 and HHV7 in patients according to age

\begin{tabular}{|c|c|c|c|c|}
\hline & $\begin{array}{l}0-2 \text { years } \\
\text { N0. \% }\end{array}$ & $\begin{array}{l}<2-4 \text { years } \\
\text { N0. \% }\end{array}$ & $>4$ years & $\mathbf{P}$ \\
\hline EBV $(n=19)$ & $6 \quad 31.6 \%$ & $6 \quad 31.6 \%$ & $7 \quad 36.8 \%$ & $\mathrm{P}=0.3$ \\
\hline HHV6 $(n=10)$ & $20 \%$ & $40 \%$ & $4 \quad 40 \%$ & $\mathrm{P}=0.9$ \\
\hline HHV7 (n=8) & $25 \%$ & $0 \%$ & $75 \%$ & $\mathrm{P}=0.1$ \\
\hline
\end{tabular}

Table.5 Comparison between EBV positive and EBV negative patients

\begin{tabular}{|c|c|c|c|}
\hline & $\begin{array}{r}\text { EBV+ } \\
(n=19) \\
\text { No. } \%\end{array}$ & $\begin{array}{l}\text { EBV- } \\
(n=41) \\
\text { No. } \%\end{array}$ & $\mathbf{P}$ \\
\hline $\begin{array}{l}\text { Sex } \\
\text { Male } \\
\text { Female }\end{array}$ & $\begin{array}{ll}17 & 89.5 \% \\
2 & 10.5 \%\end{array}$ & $\begin{array}{ll}27 & 65.8 \% \\
14 & 34.2 \%\end{array}$ & $\mathrm{P}=0.05$ \\
\hline Age & $5.00 \pm 3.7$ & $3.9 \pm 2.5$ & $\mathrm{P}=0.3$ \\
\hline Fever & $12 \quad 63.2 \%$ & $7 \quad 17.1 \%$ & $\mathrm{P}=0.4$ \\
\hline Hepatomegaly & $9 \quad 47.4 \%$ & $6 \quad 14.6 \%$ & $\mathrm{P}=0.01$ \\
\hline Lymphadenopathy & $12 \quad 63.2 \%$ & $7 \quad 17.1 \%$ & $\mathrm{P}=0.4$ \\
\hline Mucositis & $14 \quad 34.1 \%$ & $7 \quad 17.1 \%$ & $\mathrm{P}=0.5$ \\
\hline $\begin{array}{l}\text { Total leucocytic counts } x \\
10^{3} / \mathrm{mm}^{3}\end{array}$ & $46.5 \pm 38.5$ & $17.7 \pm 14.7$ & $\mathrm{P}=0.04$ \\
\hline $\mathrm{HB}$ g/dl & $8.0 \pm 2.6$ & $8.1 \pm 2.6$ & $\mathrm{P}=0.9$ \\
\hline $\operatorname{RBCsx}^{10} / \mathrm{I}$ & $3.7 \pm 1.0$ & $3.7 \pm 0.8$ & $\mathrm{P}=0.9$ \\
\hline Platelets $\times 10^{3} / \mathrm{mm}^{3}$ & $48.3 \pm 35.8$ & $52.2 \pm 41.14$ & $\mathrm{P}=0.6$ \\
\hline Neutrophils $\times 10^{3} / \mathrm{mm}^{3}$ & $2.9 \pm 1.5$ & $3.3 \pm 2.7$ & $\mathrm{P}=0.5$ \\
\hline Lymphocytes $x 10^{3} / \mathrm{mm}^{3}$ & $38.8 \pm 3.2$ & $13.4 \pm 10.6$ & $\mathrm{P}=0.02$ \\
\hline $\begin{array}{l}\text { Type of ALL } \\
\text { B-ALL } \\
\text { T-ALL }\end{array}$ & $\begin{array}{ll}17 & 89.5 \% \\
2 & 10.5 \%\end{array}$ & $\begin{array}{ll}15 & 36.6 \% \\
26 & 63.4 \%\end{array}$ & $\mathrm{P}=0.0001$ \\
\hline
\end{tabular}

NB: EBV+: EBV positive

EBV-: EBV negative 
Table.6 Comparison between HHV6 positive and HHV6 negative patients

\begin{tabular}{|c|c|c|c|}
\hline & $\underset{(n=10)}{\text { HHV6+ }}$ & $\begin{array}{l}\text { HHV6- } \\
(\mathbf{n}=50)\end{array}$ & \\
\hline $\begin{array}{l}\text { Sex } \\
\text { Male } \\
\text { Female }\end{array}$ & $\begin{array}{ll}8 & 80 \% \\
2 & 20 \%\end{array}$ & $\begin{array}{ll}36 & 72 \% \\
14 & 28 \%\end{array}$ & $\mathrm{P}=0.5$ \\
\hline Age & 4.62 .1 & 4.63 .6 & $\mathrm{P}=0.9$ \\
\hline Fever & $4 \quad 40 \%$ & $1530 \%$ & $\mathrm{P}=0.4$ \\
\hline Hepatosplenomeegaly & $8 \quad 80 \%$ & $7 \quad 46.7 \%$ & $\mathrm{P}=0.0001$ \\
\hline Lymphadenopathy & $5 \quad 50 \%$ & $1326 \%$ & $\mathrm{P}=0.04$ \\
\hline mucositis & $220 \%$ & $1938 \%$ & $\mathrm{P}=0.2$ \\
\hline $\begin{array}{l}\text { Total leucocytic counts } x \\
10^{3} / \mathrm{mm}^{3}\end{array}$ & 18.413 .0 & $44.3 \quad 33.5$ & $\mathrm{P}=0.3$ \\
\hline HB g/dl & $7.5 \pm 2.1$ & $8.2 \pm 2.7$ & $\mathrm{P}=0.4$ \\
\hline RBCsx $10^{6} / I$ & $3.5 \pm 0.7$ & $3.7 \pm 0.9$ & $\mathrm{P}=0.2$ \\
\hline Platelets $\times 10^{3} / \mathrm{mm}^{3}$ & $48.04 \pm 30.04$ & $53.1 \pm 41.1$ & $\mathrm{P}=0.7$ \\
\hline Neutrophils $\times 10^{3} / \mathrm{mm}^{3}$ & $2.7 \pm 1.7$ & $3.1 \pm 2.02$ & $\mathrm{P}=0.5$ \\
\hline Lymphocytes $\times 10^{3} / \mathrm{mm}^{3}$ & $15.04 \pm 11.9$ & $37.03 \pm 27.5$ & $\mathrm{P}=0.3$ \\
\hline $\begin{array}{l}\text { Type } \\
\text { B-ALL } \\
\text { T-ALL }\end{array}$ & $\begin{array}{ll}8 & 80 \% \\
2 & 20 \%\end{array}$ & $\begin{array}{ll}24 & 48 \% \\
26 & 52 \%\end{array}$ & $\mathrm{P}=0.4$ \\
\hline
\end{tabular}

Table.7 Comparison between HHV7 positive and HHV7 negative patients

\begin{tabular}{|c|c|c|c|}
\hline & 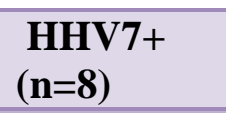 & $\begin{array}{l}\text { HHV7- } \\
(n=52)\end{array}$ & \\
\hline $\begin{array}{l}\text { Sex } \\
\text { Male } \\
\text { Female }\end{array}$ & $\begin{array}{ll}6 & 75 \% \\
2 & 25 \%\end{array}$ & $\begin{array}{ll}38 & 73.1 \% \\
14 & 26.9 \%\end{array}$ & $\mathrm{P}=0.6$ \\
\hline Age & $8.7 \pm 4.8$ & $4.0 \pm 2.6$ & $\mathrm{P}=0.0001$ \\
\hline Fever & 0 & $1936.5 \%$ & \\
\hline Hepatosplenomegaly & 0 & $15 \quad 28.8 \%$ & \\
\hline LN & 2 & $17 \quad 32.7 \%$ & 0.5 \\
\hline mucositis & 2 & $1936.5 \%$ & 0.4 \\
\hline WBCs $x 10^{3} / \mathrm{mm}^{3}$ & $34.5 \pm 24$ & $42.2 \pm 32.0$ & 0.6 \\
\hline HB g/dl & $7.7 \pm 2.6$ & $10.3 \pm 1.4$ & $\mathrm{P}=0.0001$ \\
\hline $\operatorname{RBCsx}^{6} 0^{6} / 1$ & $3.9 \pm 1.2$ & $3.7 \pm 0.8$ & $\mathrm{P}=0.4$ \\
\hline Platelets $\times 10^{3} / \mathrm{mm}^{3}$ & $40.5 \pm 16.3$ & $54.03 \pm 41.6$ & $\mathrm{P}=0.4$ \\
\hline Neutrophils $\times 10^{3} / \mathrm{mm}^{3}$ & $2.8 \pm 0.4$ & $2.8 \pm 0.4$ & $\mathrm{P}=0.8$ \\
\hline Lymphocytes x $10^{3} / \mathrm{mm}^{3}$ & $32.9 \pm 24.00$ & $3.1 \pm 2.1$ & $\mathrm{P}=0.9$ \\
\hline $\begin{array}{l}\text { Type } \\
\text { BALL } \\
\text { TALL }\end{array}$ & $\begin{array}{ll}6 & 75 \% \\
2 & 25 \%\end{array}$ & $\begin{array}{cc}26 & 50 \% \\
26 & 50 \%\end{array}$ & $\mathrm{P}=0.2$ \\
\hline
\end{tabular}


Fig.1 The combined EBV infections with HHV6 and HHV7 among patients

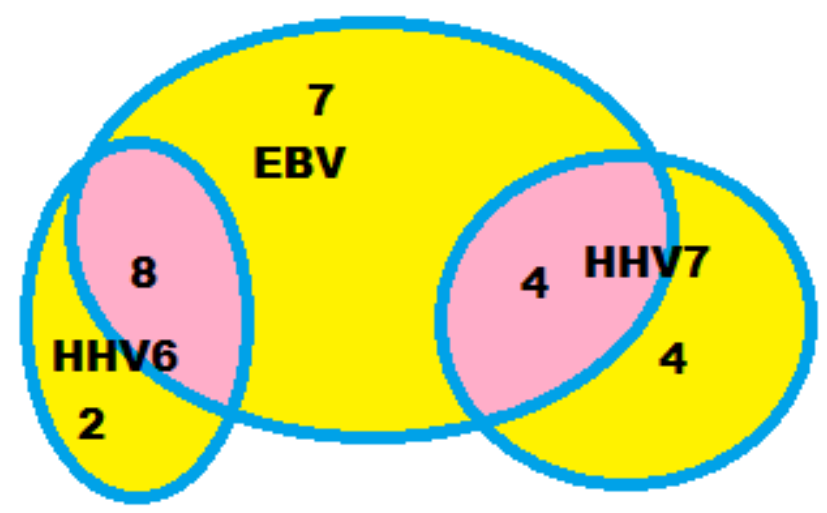

HHV6 versus EBV $\mathrm{P}=0.001$

$\mathrm{HHV7}$ versus $\mathrm{EBV} \mathrm{P}=0.2$

In the current study, there was significant association between B-ALL and EBV (89.5\%, $\mathrm{P}=0.0001$ ) that reflects the tropism of $\mathrm{EBV}$ for $B$ cells and may indicate the close association of EBV infection is with the occurrence of B-ALL as indicated by previous finding ${ }^{[13]}$. However, EBV may also target $\mathrm{T}$ lymphocytes and this was described previously ${ }^{[20]}$. There are cumulative evidences that EBV induces malignant transformation of T-lymphocytes leading to EBV associated Hemophagocytic Lymphohistiocytosis, chronic active EBV infection $\mathrm{T}$ - or NK-cell lymphoproliferative diseases and T-ALL ${ }^{[21]}$. In vitro study supported the role of EBV in etiology of TALL ${ }^{[22]}$.

In the present study, EBV+ALL had the characteristic clinical signs and laboratory findings associated with EBV namely significant hepatosplenomegaly $(47.4 \%$, $\mathrm{P}=0.01$ ), with significant increase of total leucocytes counts (mean \pm SD46.5 \pm 38.5, $\mathrm{P}=0.04$ ) and absolute lymphocytosis (mean \pm $\mathrm{SD} 38.8 \pm 3,2, \mathrm{P}=0.02)$. These clinical signs are described to be clues for $\mathrm{EBV}$ reactivation in lymphoid tissues ${ }^{[23]}$. The presence of clinical signs of EBV reactivation in children with ALL associated by EBV viremia as detected by real time PCR, denotes that molecular method is suitable for diagnosis of EBV in those patients. Similar result was reported in patients with nasopharyngeal carcinoma by Ambinder (2017) ${ }^{[24]}$.

The use of real time PCR for detection of EBV DNA free in plasma was used in the present study as it was reported to yield good results as that used for mononuclear cells ${ }^{[24]}$. Molecular laboratory investigations suggest a role for viral load measurement in predicting various EBV-associated tumors such as lymphoproliferative disorder and Hodgkin's disease. The high viremia load may be associated with development and even in the prognosis of ALL ${ }^{[25]}$.

The distinguished finding of the present study was the significant association between EBV and HHV6 among patients with ALL. Previous studies have proposed that more than one type of herpes viruses potentiate the pathological effects in infectious 
mononucleosis as well as among other diseases such as chronic fatigue syndrome and post transplantation disorders ${ }^{[26,27]}$. However, this finding is contradictory with other reported by Morales-Sánchez et al., $2014^{[28]}$. The difference may be due to the difference in the geographic locations and the difference in the number of the included patients.

In the present study, other herpes viruses than EBV were studied namely HHV6 and HHV7. HHV6 has been suggested to have a role in hematological malignancies, though it is a lytic virus. This is due to its capability of transforming DNA in vitro studies $\left[{ }^{29,30]}\right.$. Even, the genome of HHV-6 has been shown to be integrated to peripheral blood mononuclear cell DNA and its DNA sequences were isolated from pathologic samples of Hodgkin's disease ${ }^{[31]}$ and even from peripheral blood mononuclear cells from patients with ALL and with TALL ${ }^{[32]}$.

In the present study, there were statistically significant higher prevalence of HHV6 and HHV7 among ALL (16.7\%, $13.3 \%$ respectively) compared to healthy children (3.3\% and $8.3 \%$ respectively, $\mathrm{P}=0.0001)$. These findings are contradictory to previous findings reporting lower prevalence of HHV6 and HHV7 among patients with ALL $[28,33]$ The presence of high prevalence of HHV6 and HHV7 in the current study may indicate the role of different geographical regions in the epidemiology of the association of viral infections with development of certain diseases. Moreover, herpes viruses usually act as potentiating pathogenic factors for each other in infectious mononucleosis. Whether this mechanism also contributes to the pathogenesis of ALL or not, needs further extensive studies.

The supporting evidence from the present study that HHV6 and HHV7 may be involved in infectious mononucleosis disease that may be associated with pathogenesis of ALL, were the association of significant clinical signs associated with lymphoid system involvement such as hepatosplenomegaly with these viral infections.

The age distribution of EBV, HHV6 and HHV7 among children with ALL had no significant association with certain age. However, there was increase in the prevalence of EBV (36.8\%), HHV6 (40\%) and HHV7 $(75 \%)$ in age above 4 years. Moreover, there was significant predominance of males among infected children. Similar results were reported from previous study from Burkina Faso with more prevalence of EBV and HHV6 in male patients below 5 years ${ }^{[34]}$.

In conclusion, EBV, HHV6 and HHV7 viruses were present in high rates in ALL which suggest a role for these viruses in pathogenesis of ALL. Further studies are required to validate this hypothesis.

\section{References}

1.Henle G, Henle W, Clifford P, et al. Antibodies to Epstein-Barr virus in Burkitt's lymphoma and control groups. J Natl Cancer Inst. 1969; 43: 1147-1157.

2. Klein G, Clifford P, Henle G, et al. EBVassociated serological patterns in a Burkitt lymphoma patient during regression and recurrence. Int $\mathbf{J}$ Cancer. 1969; 4: 416-421.

3. Moore PS, Chang Y. Why do viruses cause cancer? Highlights of the first century of human tumour virology. Nature Reviews Cancer. 2010;10(12):878889.

4.Wen KW, Damania B. Kaposi sarcomaassociated herpesvirus (KSHV): molecular biology and oncogenesis. Cancer Letters. 2010; 289(2): 140- 
150.

5. Styczynski J, TridelloG, Gil L, et al. Impact of Donor Epstein- Barr virus serostatus on the incidence of graft- versus- host disease in patients with acute leukemia after hematopoietic stem- cell transplantation: a study from the acute leukemia and infectious diseases working parties of the European Society for Blood and Marrow Transplantation. J Clin Oncol. 2016; 34:2212-2220.

6. Thorley- Lawson DA. Epstein- Barr virus: exploiting the immune system. Nat Rev Immunol. 2001; 1: 75-82.

7. Kimura H, Kawada J, Ito Y. Epstein- Barr virus- associated lymphoid malignancies: the expanding spectrum of hematopoietic neoplasms. Nagoya $\mathbf{J}$ Med Sci. 2013; 75:169-179.

8. Mullins TB, Krishnamurthy K. Roseola Infantum (Exanthema Subitum, Sixth Disease) [Updated 2017 Dec 4]. In: StatPearls [Internet]. Treasure Island (FL): StatPearls Publishing; 2018 Jan-. Available from: https://www.ncbi.nlm. nih.gov/books/NBK448190/

9. Traore L, Nikiema O, Ouattara AK, Compaore TR, Soubeiga ST, Diarra B, Obiri-Yeboah D, Sorgho PA, Djigma FW, Bisseye C, Yonli AT, Simpore J.EBV and HHV-6 Circulating Subtypes in People Living with HIV in Burkina Faso, Impact on CD4 T cell count and HIV Viral Load. Mediterr J Hematol Infect Dis. 2017 Sep 1;9(1):e2017049. doi: 10.4084/ MJHID.2017.049. eCollection 2017.

10. Nefzi F, Ben Salem NA, Khelif A, Feki S, Aouni M, Gautheret-Dejean A Quantitative analysis of human herpesvirus-6 and human cytomegalovirus in blood and saliva from patients with acute leukemia. J Med Virol. 2015; 87(3): 451-60. doi: 10.1002/jmv.24059. Epub 2014 Aug 27.

11. Vardiman JW, Thiele J, Arber DA, Brunning RD, Borowitz MJ, Porwit A, Harris NL, Le Beau MM, HellströmLindberg E, Tefferi A, Bloomfield CD. The 2008 revision ofthe World Health Organization (WHO) classification of myeloid neoplasms and acute leukemia: rationale and important changes. Blood. 2009 30; 114(5):937-51. doi: 10.1182/blood2009-03-209262.

12. Wada K, Mizoguchi S, Ito Y, Kawada J, Yamauchi Y, Morishima T, Nishiyama Y, Kimura H. Multiplex real-time PCR for the simultaneous detection of herpes simplex virus, human herpesvirus 6, and human herpesvirus 7. Microbiol Immunol. 2009 Jan; 53(1): 22-9. doi: 10.1111/j.13480421.2008.00090.x.

13.Miao H, Ma N, Lu W, Luo B. Correlations between Epstein-Barr virus and acute leukemia. J Med Virol. 2017; 89(8): 1453-1460. doi: 10.1002/jmv.24797. Epub 2017 Mar 6.

14. Ahmed HG, Osman SI, Ashankyty IM. 2012. Incidence of Epstein-Barr virus in pediatric leukemia in the Sudan. Clinical

lymphoma, Myeloma and Leukemia 12(2):127-131.

15. Loufty SA, Alam El-Din HM, Ibrahim MF, et al. Seroprevalence of herpes simplex virus type 1 and 2, EpsteinBarr virus and cytomegalovirus in children with acute lymphoblastic leukemia in Egypt. Saudi Med J 2006; 27:1139-45

16. Ateyah ME, Hashem ME, Abdelsalam M. Epstein-Barr virus and regulatory $\mathrm{T}$ cells in Egyptian paediatric patients with acute B lymphoblastic leukaemia. J Clin Pathol. 2017; 70(2): 120-125. 
doi: 10.1136/jclinpath-2016-203803. Epub 2016 Jul 25.

17. Lustosa de Sousa DW, de Almeida Ferreira FV, Cavalcante Félix FH, et al. Acute lymphoblastic leukemia in children and adolescents: prognostic factors and analysis of survival. Rev Bras Hematol Hemoter 2015; 37: 223 9.

18. Mahjour SB, Ghaffarpasand F, Fattahi MJ, et al. Seroprevalence of human herpes simplex, hepatitis B and Epstein barr viruses in children with acute lymphoblastic leukemia in southern Iran. Pathol Oncol Ref 2010; 6:579-82

19. Grimm T, Schneider S, Naschberger E, Huber J, Guenzi E, Kieser A, Reitmeir P, Schulz TF, Morris CA, Sturzl M. 2005. EBV latent membrane protein-1 protects B cells from apoptosis by inhibition of BAX. Blood 105(8):3263-3269.

20.Kanavaros P, Lescs MC, Briere J, Divine M, Galateau F, Joab I, Bosq J, Farcet JP, Reyes F, Gaulard P. 1993. Nasal Tcell lymphoma: a clinicopathologic entity associated with peculiar phenotype and with Epstein-Barr virus. Blood 81(10):2688-2695

21. Jabbour EJ, Faderl S, Kantarjian HM. 2005. Adult acute lymphoblastic leukemia. Mayo Clinic Proceedings 80(11):1517-152

22. Paterson RL, Kelleher C, Amankonah TD, Streib JE, Xu JW, Jones JF, Gelfand EW. 1995. Model of Epstein-Barr virus infection of human thymocytes: expression of viral genome and impact on cellular receptor expression in the T-lymphoblastic cell line, HPB-ALL. Blood 85(2):456-464

23. Maurmann S, Fricke L, Wagner HJ, Schlenke P, Hennig H, Steinhoff J, Jabs WJ. Molecular parameters for precise diagnosis of asymptomatic
Epstein-Barr virus reactivation in healthy carriers. J Clin Microbiol. 2003; 41(12):5419-28.

24. Ambinder RF. Plasma Epstein-Barr Virus DNA for Screening. N Engl J Med. 2017, 10; 377(6): 584-585. doi: 10.1056/NEJMe1706815.

25. Fan H, Gulley ML. Epstein-Barr viral load measurement as a marker of EBV-related disease. Mol Diagn. 2001 Dec;6(4):279-89.

26. Chapenko S, Krumina A, Logina I, et al. Association of active human herpesvirus-6, -7 and parvovirus B19 infection with clinical outcomes in patients with myalgic encephalomyelitis/chronic fatigue syndrome. Advances in Virology. 2012; 2012:7.205085

27. Wang X, Yang K, Wei C, Huang Y, Zhao D. Coinfection with EBV/CMV and other respiratory agents in children with suspected infectious mononucleosis. Virology J. 2010; 7, 247.

28. Morales-Sánchez A, Pompa-Mera EN, Fajardo-Gutiérrez A, AlvarezRodríguez FJ, Bekker-Méndez VC, Flores-Chapa Jde D, et al., EBV, HCMV, HHV6, and HHV7 screening in bone marrow samples from children with acute lymphoblastic leukemia. Biomed Res Int.; 2014:548097. doi: $10.1155 / 2014 / 548097$.

29. Razzaque A, Williams $\mathrm{O}$, Wang $\mathrm{T}$ and Rhim JS. Neoplastic transformation of immortalized human epidermal keratinocytes by two HHV-6 DNA clones. Virology. 1993, 195: 113-120.

30. Thompson J, Choudhury S, Kashanchi F, Doniger J, Berneman Z, Frenkel N and Rosenthal LJ. A transforming fragment within the direct repeat region of human herpesvirus type 6 that transactivates HIV-1. Oncogene. 1994, 9: 1167-1175 
31. Di Luca D, Dolcetti R, Mirandola P, De Re V, Secchiero P, Carbone A, Boiocchi $\mathrm{M}$ and Cassai E. Human herpesvirus 6: a survey of presence and variant distribution in normal peripheral lymphocytes and lymphoproliferative disorders. J Infect Dis. 1994, 170: 211-215

32. Braun DK, Pellett PE and Hanson CA. Presence and expression of human herpesvirus 6 in peripheral blood mononuclear cells of S100-positive, Tcell chronic lymphoproliferative disease. J Infect Dis. 1995, 171: 13511355

33. Gentile, G., Mele, A., Ragona, G., Faggioni, A., Zompetta, C., Tosti, M.
E., Mandelli, F. Human herpes virus-6 seroprevalence and leukaemias: a case-control study. British Journal of Cancer, 1999. 80(7), 1103-1106. http://doi.org/10.1038/sj.bjc.6690471

34. Traore, L., Nikiema, O., Ouattara, A. K., Compaore, T. R., Soubeiga, S. T., Diarra, B., Simpore, J.. EBV and HHV-6 Circulating Subtypes in People Living with HIV in Burkina Faso, Impact on CD4 $\mathrm{T}$ cell count and HIV Viral Load. Mediterranean Journal of Hematology and Infectious Diseases, 2017, 9(1), e2017049. http://doi.org/10.4084/MJHID.2017.04 9.

\section{How to cite this article:}

Mohamed AniesRizk and Ahmad Darwish. 2019. Study of Epstein Barr virus, Human Herpes 6 and Human Herpes 7 in Children with Acute Lymphoblastic leukemia. Int.J.Curr.Microbiol.App.Sci. 8(03): 251-262. doi: https://doi.org/10.20546/ijcmas.2019.803.032 